\title{
Past, current and potential resources of carbon and above-ground plant biomass in the landscape with heaths in some selected areas of the Tuchola Forest
}

\author{
*Marcin Jarzębski, *Andrzej Nienartowicz, *Milosz Deptuła, \\ *Jakub W. Bubnicki **Dominik J. Domin \\ * Laboratory of Ecological Processes Modelling, Institute of Ecology and Environment Protection, \\ Nicolaus Copernicus University, Gagarina 9, 87-100 Toruń, Poland, e-mail: anienart@umk.pl \\ ** Departament of Urban and Recreation Studies, Institute of Geography, Faculty of Biology and Earth Sciences, \\ Nicolaus Copernicus University, Gagarina 9, 87-100 Toruń, Poland, e-mail: djdomin@umk.pl
}

\begin{abstract}
Applying the GIS technologies, historical and contemporary cartographic materials, data coming from the forest inventory and indices of biomass state, the total biomass and biomass for individual layers of forest and non-forest phytocoenoses, the real and potential biomass was assessed, as well as current and potential carbon resources in that biomass in four nature objects. The investigated objects were characterized by different spatial size, as well as by different intensity of human economic activities and different status of nature conservation. Those were: the Tuchola Forest National Park, the Zaborski Landscape Park, as well as the areas of the so-called (forest) demesne of Zabory and the (field) demesne of Tuchola in the former District (Starosty) of Tuchola. In the case of both demesnes, the biomass state was assessed, as well as the extent of its displacement caused by economic human activities, both nowadays and in the past, i.e. for the year 1796 and 2008. The smallest difference in the state of potential and actual biomass was recorded in the National Park. The loss here amounted to $28.44 \%$. The biggest differences occurred in the field demesne in 1796 . The loss here reached $76.47 \%$. It was also observed that nowadays the loss slightly decreased, reaching the level of $73.97 \%$. In the demesne of Zabory, the increase of biomass state was considerably higher during the discussed period. In 1796, when heaths and poor xerothermic meadows covered relatively large areas and were exploited as sheep's grazing lands, the biomass loss amounted here to $69.32 \%$ and in 2008 to $51.87 \%$. The increase of biomass state and at the same time the reduction in biomass losses, calculated in relation to the potential, was brought here about mainly by establishing the Prussian Forest Inspectorate Zwangshof in 1890 and by afforestation of agricultural and fallow lands, which was done by Polish forest inspectorates in the 20th century, particularly during several years after the 2nd World War.
\end{abstract}

Key words: carbon in plant biomass, deforestation, forest inventory, GIS, heathlands, historical maps, land use, landscape structure, natural vegetation, potential vegetation map, protected areas, reforestation.

\section{Introduction}

Specific landscape structure, as a consequence of human impact on the nature, becomes particularly evident on higher levels of biosphere organization. In the hierarchical system of biosphere organization, a landscape - defined also as a physiocoenosis - is a mosaic of ecosystems. According to the definition by Ryszkowski (1984), this is the level of biosphere organization, at which there is a possibility to optimize the routes of energy flow and matter circulation through controlling the structure and spatial distribution of ecosystems. In the past, this possibility was 
used to a different extent in order to prevent unfavourable landscape processes triggered by man.

The main parameter determining the intensity of human activities in the landscape is the cultural energy consumption by a local community, expressed in physical units of energy per unit of surface area. Whereas, vegetation is the main element of ecosystems' structure, and at the same time of the landscape, which depending on natural habitat factors and anthropogenic interactions differentiates into particular types of phytocoenoses, formed by different combinations of tree, shrub, herbaceous and low shrub species, as well as species of bryophytes and lichens. Within one habitat, as a consequence of intentional or unintentional human activity, different types of phytocoenoses may occur, e.g. in the habitat of fresh pine forest, both patches of old forest and logging areas can be observed, as well as developmental phases of forest spontaneously or artificially regenerating in the silviculture process controlled by a forester. Also non-forest communities may occur, such as heaths, dunes, arable fields and meadows, indicating that landscape transformations may also include changes in vegetation formations from forest to non-forest ones. The information about the structure of previous landscape states comes, among others, from historical cartographic materials. Whereas, maps of potential vegetation could be used as the reference point for the evaluation of the past and current states of the landscape.

Apart from species composition and quantitative relationships between species, the element of phytocoenoses' structure that influences their functioning is the amount of plant biomass produced in the process defined as primary production. Human influence on the size of primary production and the stock of plant biomass accumulated in the landscape ensues mainly through two processes - displacement of vegetation, which results from replacing the plants by elements of technical and social infrastructure, such as construction of housing developments, towns or roads connecting those settlement units, as well as technological changes in plant production and annual crop acquisition, i.e. food, fodder for farm animals, fuel, building timber, etc. The course of those processes and their influence on carbon flows in natural and socio-economic subsystems, exerted over a long time, are presented by more and more numerous papers within the scope of ecology and historical geography (Johnson \& Earle 1987; Crumley 1993; Williams 2000; Schandl \& Schulz 2002; Gingrich et al. 2007; Erb et al. 2008).

In the ecology, the differences between potential and actual net primary production, together with the yield obtained in each year, are defined as an index of human appropriation of net primary production, that is HANPP. This term was introduced by Vitousek et al. $(1986,1997)$ and then developed by Helmut Haberl, who, together with collaborators, evaluated this parameter for the whole area of contemporary Austria (Haberl \& Geissler 2000; Haberl et al. 2001, 2002, 2007a, b; Erb et al. 2007). According to their assessment, at present this index reaches $22-39 \%$ at the global scale. Until now, the appropriation of primary production has not been assessed for Polish territories, both for contemporary states and for past developmental phases of our landscapes.

Apart from changes in plant biomass produced every year, i.e. primary production, the contemporary ecology also intensively investigates the loss or increase of living plant biomass accumulated over many years. This value, defined as the stock of plant biomass (standing crops), is estimated at the level of ecosystems, landscapes or a whole country. The research has been carried out on the influence exerted by changes in the accumulated plant biomass and carbon contained therein on the enhancement or mitigation of the so-called greenhouse effect, as well as the related climatic changes and biodiversity in individual regions of the world. The above-ground standing crop and the aboveground carbon stocks of terrestrial plant communities in Austria were calculated by Haberl et al. (2001), Weisz et al. (2001) and Erb (2004). The paper by Titlyanova and Kosykh (2000) is an example of assessments based both on estimations of primary production and plant biomass stock in a large region - a forest-steppe zone in Western Siberia.

In Poland, the Tuchola Forest is one of the investigation areas where relationships between cultural metabolism and the landscape structure are studied, as well as between the primary production size, the state of plant biomass and the amount of carbon accumulated therein. The magnitude of cultural metabolism in the Laska forest district included within the Forest Division of Przymuszewo and the Zaborski Landscape Park was studied by Nienartowicz (1992, 1996). Whereas, Barcikowski and Loro (1993) did the evaluation of losses in primary production within the district of Laska, resulting from clear felling. Based on the data on primary production and the biomass state obtained from the latter study, Nienartowicz and Barcikowski (1996) evaluated the extent of ecological stability in the forest district Laska, through measuring the so-called biophysical capital and the negentropic cost according to the method proposed by Giampietro and Pimentel (1991), as well as Giampietro et al. (1992). Miscellaneous methods of ecological energetics and the results of their applications in the analysis of the whole Przymuszewo Forest Division and the Promotional Forest Complex ,Tuchola Forest”, which comprises five other forest divisions, was presented by Nienartowicz $(1999,2002)$. The author together with a group of associates (Nienartowicz 1996; Nienartowicz et al. 2003) also carried out multifaceted analysis of biological and cultural metabolism in the forest village of Asmus located within the forest district of Laska. Moreover, Nienartowicz et al. $(1998,2002)$ also completed the evaluation 
of structural changes in the landscape, the state of plant biomass and the level of organic carbon accumulated in this biomass as a consequence of afforestation in one of the landed estates with the area of ca. 612 ha, during the development of the Prussian Forest Inspectorate Zwangshof in the latter half of the 19th century. In the aforementioned papers, the comparison was performed between the conditions at the end of the 20th century and before the development of the Prussian forest economic unit, i.e. before 1890. Whereas Deptuła (2006) evaluated the level of carbon accumulation at a larger spatial scale, namely in the territory (ca. $10.5 \mathrm{~km} \times 11 \mathrm{~km}$ ) reproduced on one sheet of the Prussian topographic map Sec. Rollbick at the scale of $1: 25,000$ according to the state from 1874 . Further states of temporal series worked out by this author comprise the years of 1926, 1953, 1966, 1976 and 1998. Description of relationships between the intensity of human activities expressed by cultural metabolism and the landscape structure defined on the basis of the satellite image Landsat ETM+ at the level of the whole Tuchola Forest region was presented by Nienartowicz and Domin (2007). Nienartowicz et al. (2008) also presented the cultural metabolism and the landscape structure from the historical aspect in the territory of the so-called demesne of Zabory included in the Tuchola district authority.

The present paper deals with the evaluation of plant biomass losses as a consequence of the influence of the production-cultural subsystem on the nature within few areas of the Tuchola Forest. Those are areas of the Tuchola Forest National Park, as well as the whole area of the Zaborski Landscape Park. Those areas of high nature conservation status may constitute the reference point for the evaluation of the natural state (naturalness) of areas where intensity of human impact on the nature is much higher. Among areas of this type, there were areas included in the past (the 15th-18th century) within two different, in respect of land use, economic units of the Tuchola district authority, i.e. the (forest) demesne of Zabory and the (field) demesne of Tuchola. In this paper, using cartographic sources and forest databases, as well as applying the GIS technology, losses in plant biomass were compared according to the state from 1796 and 2008.

\section{The study area}

The Tuchola Forest National Park was created in 1996. It is situated in the Pomerania province (Fig. 1), to the north of the town of Chojnice and to the east of Lake Charzykowskie. Land relief of the park was developed during the last Baltic glaciation (the Pomeranian stadial). The dominating geomorphological form are sandy outwash plains of the Brda River, situated at the longitude of 130-150 m asl, inclined towards the south and covered with extensive

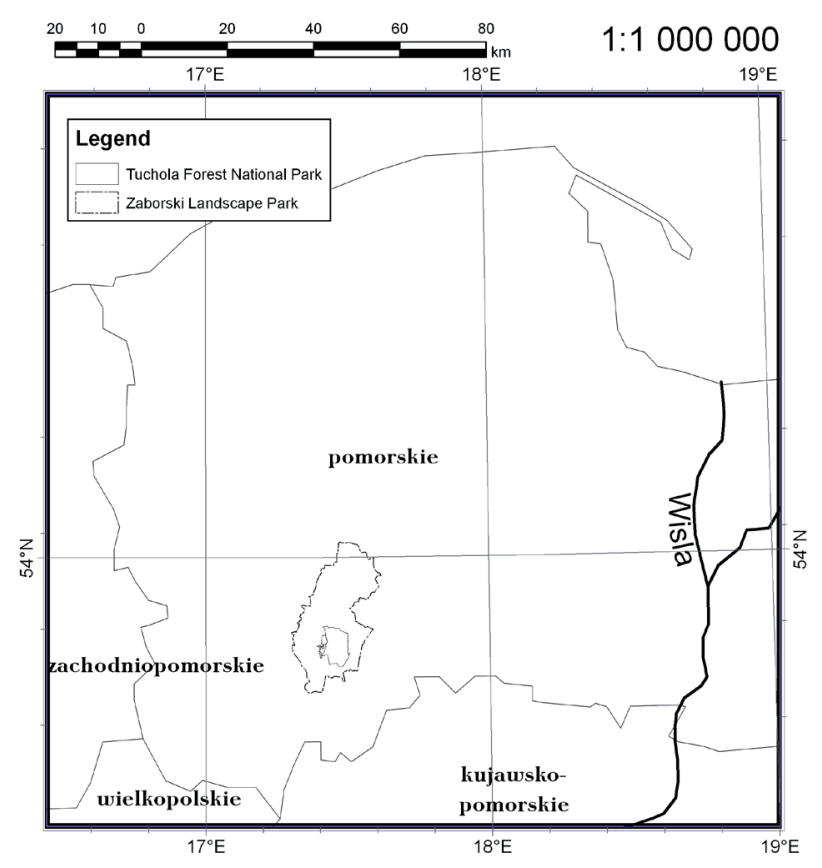

Figure 1. Location of the Tuchola Forest National Park and the Zaborski Landscape Park

pine forests. Struga Siedmiu Jezior (the Stream of Seven Lakes) is the main watercourse in the Park, crossing the Park along the line East - West and flowing into Lake Charzykowskie. Also the Brda River flows through this lake, being the main river of the whole Tuchola Forest region.

The area of the park amounts to 4,613.04 ha, most of which is covered by forests $(82.72 \%)$, as well as lakes and rivers $(11.72 \%)$. Only a small part of the area is covered with lines of forest surface division, as well as arable fields, meadows and housing estate areas (6.36, 5.06 and $3.94 \%$ respectively). Fresh pine forest is the dominating forest habitat type in the National Park $(90.33 \%$ of the afforested forest area, which amounts to 3,815.82 ha). A small part of the forest area is covered with habitats of dry $(0.18 \%)$ and humid pine forests $(0.01 \%)$, as well as mixed coniferous forests $(7.10 \%)$, mixed forests $(2.04 \%)$ and deciduous forests $(0.34 \%)$.

Scots pine evidently dominates in the tree stand. Pine tree stands make up as much as $96.81 \%$ of the forest area. Small areas are covered with birch $(1.73 \%)$, spruce $(0.68 \%)$, alder $(0.53 \%)$, oak $(0.13 \%)$, larch $(0.06 \%)$ and poplar $(0.06 \%)$ tree stands. As far as the age structure is concerned, forest stands of the following age classes cover the largest areas: the third (26.15\%), the second (18.67\%) and the fifth class $(18.34 \%)$. Forest stands in the youngest age class (1-20 years old) cover $5.09 \%$ of the forest area and forest stands of over 100 years old $-19.11 \%$ (i.e. 729.14 ha). 
Within the Park's area, 10 areas with strict nature conservation policy were delimited, which altogether cover 324.30 ha, i.e. $7.04 \%$ of its total area (www.park.borytucholskie.info). Over the area of 4,209.78 ha (91.26\%), partial nature conservation is being implemented, both non-invasive (preservative), as well as active one. The remaining part of the Park, that is 78.96 ha $(1.71 \%)$ includes areas of landscape conservation. In the areas of strict nature conservation, there are many lakes, including lobelia lakes, which are great peculiarities of the Tuchola Forest National Park. Also wetlands and peat bogs, surrounded by natural forest communities, cover a significant area here.

The dominating forests in the Tuchola Forest National Park constitute an efficient buffer for lakes, wetlands and peat bogs, as well as they sustain high species diversity over the whole area. Altogether there are 640 species of vascular plants in the Tuchola Forest National Park, including more than 70 rare species, rare and protected species (www.park.borytucholskie.info). Also, the occurrence of 155 species of mosses and 26 species of liverworts was confirmed. The list of lichens comprises 231 species, including 20 primaeval-forest relics and 60 legally protected species. So far 315 species of macroscopic fungi were described. Also fauna of invertebrates is rich. Within particular taxonomic groups of vertebrates, the following statistics was confirmed: 20 fish species, 9 species of amphibians, 5 species of reptiles, 100 species of birds, including 87 species of breeding avifauna. Among 37 species of mammals, beaver, boar, roe deer and deer have the strongest direct effect on the state of living plant biomass (www.park.borytucholskie.info).

The Zaborski Landscape Park is situated around the Tuchola Forest National Park. It was created in 1990 (www. zaborypark.eco.pl). The Tuchola Forest National Park was included within the Landscape Park in 1996. Today, some of the areas of the Landscape Park constitute a buffer zone of the Tuchola Forest National Park.

The Zaborski Landscape Park is situated within the territory of two communes, Brusy and Chojnice. Its area amounts to 34,026 ha. Forests dominate in the land use structure. They cover $72.17 \%$ of its area, whereas division lines and roads - only $6.36 \%$. Forest areas are mainly included in two forest divisions - Rytel and Przymuszewo. Only a small part of state forests belongs to the Forest Division of Czersk. All aforementioned forest divisions are under the authority of the Regional Directorate of State Forests in Toruń. Only a small part of the forest area is private.

Within the forest area of the Zaborski Landscape Park, similarly like in the Tuchola Forest National Park, fresh pine forest is the dominating habitat type. Those habitats, developed on extensive outwash plains, are overgrown by the association Leucobryo-Pinetum. Scots pine dominates in the species structure of tree stands, whereas the third class dominates in the age structure of tree stands. A considerable part of the Landscape Park, particularly its northern area is covered with secondary pine forests, reconstructed in heathlands, poor grazing lands and degraded farmlands. Those pine forests are characterized by lower habitat fertility and due to their lower values of NDVI, they are clearly distinguishable in satellite images (Kunz et al. 2000). They are included within the syntaxa of CladonioPinetum and Leucobryo-Pinetum callunetosum. Deciduous forests cover a much smaller area. Among them, alder forests dominate, classified as associations of Ribeso nigriAlnetum and Sphagno squarrosi-Alnetum from the class Alnetea glutinosae, as well as Circaeo-Alnetum from the class Querco-Fagetea. They mainly cover valleys of the rivers Zbrzyca, Kulawa and Kłonecznica situated within the drainage basin of the Brda River. On hillsides of lake channels, small areas of mixed lime-oak-hornbeam forests occur: Galio sylvatici-Carpinetum and beech forests $\mathrm{Lu}$ zulo pilosae-Fagetum. A syntaxonomic rank of many forest communities is difficult to define, as they developed due to pine introduction into habitats of mixed and deciduous forests by Prussian foresters in the 19th century.

In the Zaborski Landscape Park, similarly like in the Tuchola Forest National Park, apart from forests, a significant part of the area is taken by lakes and rivers. The total area of aquatic ecosystems amounts to 3,988.09 ha, which makes up $11.72 \%$ of the Landscape Park area. Arable fields cover $5.06 \%$ of the Park's area, meadows and grazing lands $-3.94 \%$, and housing estate areas $-0.75 \%$.

Although in the past, ecosystems in the Landscape Park, particularly the terrestrial ones, were quite intensely exploited, many of them preserved natural character. In order to protect them, five nature reserves were created here, one floristic-aquatic reserve, three peat-bog reserves and one fauna reserve (www.zaborypark.eco.pl). Also projects of four further nature reserves were drawn up.

In the past, the areas of the Tuchola Forest National Park and the Zaborski Landscape Park were included in the so-called demesne of Zabory, also called the demesne of Kosobudy. The course of boundaries of all three units is presented in Figure 2. The detailed data on the economic history of the Zabory demesne is provided in the paper by Zofia Kratochwil (1981). According to this author, settlement in the Zabory Region began in the 8th century. In the 8 th century, the area was controlled by Pomeranians. Since 1308 , the area was included in the Teutonic State, within which it constituted an economic unit of the Tuchola Teutonic Commander. In 1454-1772, the area as the Zabory demesne, together with the Tuchola demesne, also called the field demesne, formed the Tuchola starosty. After the first partition of Poland, both demesnes were included in Prusy as a part of the Kwidzyn District.

Today, the area of the former Zabory demesne is mainly included in the districts of Chojnice (the commune of Choj- 


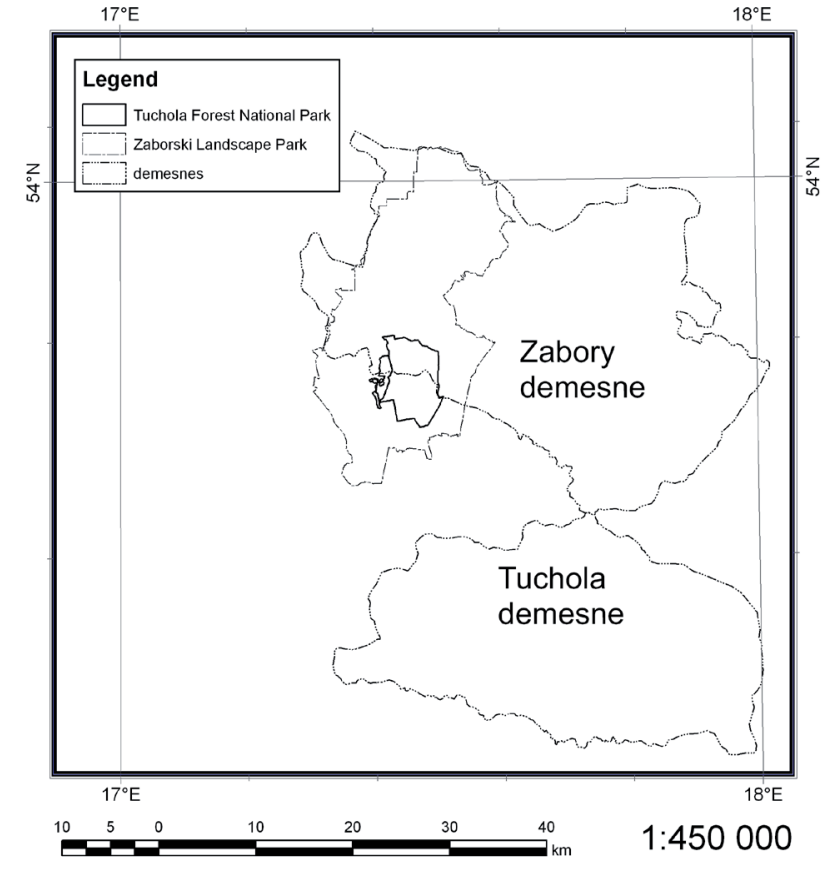

Figure 2. Boundaries of the four research objects

nice, Konarzyny, Brusy, Czersk), Bytów (the commune of Lipnica) and Kościerzyna (the commune of Karsin) in the Pomerania province. A small fragment in the south is situated within the commune of Tuchola in the Kujawy-Pomerania province. Most of the area of the field demesne is included in the Tuchola poviat (the town and the commune of Tuchola, as well as the communes of Cekcyn, Lubiewo, Gostycyn, Kęsowo) and poviats (districts) of Sępólno Krajeńskie (the commune of Kamień Krajeński) in the Kujawy-Pomerania province. A small fragment in the northern part of the field demesne is included in the Chojnice District.

The area of the Zabory demesne was calculated according to boundaries marked on the maps of Biskup and Tomczak (1955), Mikulski (1994) and Dygdała (2005) and amounted to $1,007.61 \mathrm{~km}^{2}$. The area of the field demesne was smaller and covered $729.53 \mathrm{~km}^{2}$. Both demesnes evidently differed from each other in land use structure. In the demesne of Zabory, forests made up $35.80 \%$ of the total area, waters - only $4.59 \%$ and the remaining non-forest areas (i.e. built-up areas, meadows and grazing lands, as well as arable lands) $-59.61 \%$. In the field demesne, forests covered only $25.91 \%$, waters $-2.38 \%$, and other nonforest areas covered as much as $71.71 \%$ of its total area. Boundaries and the distribution of settlement units within the area of both demesnes is presented in Figure 3. The village of Kosobudy constituted the economic centre of the Zabory demesne, whereas the town of Tuchola - of the field demesne. From the data published by Krotochwil (1981), it appears that the Zabory demesne in the latter half

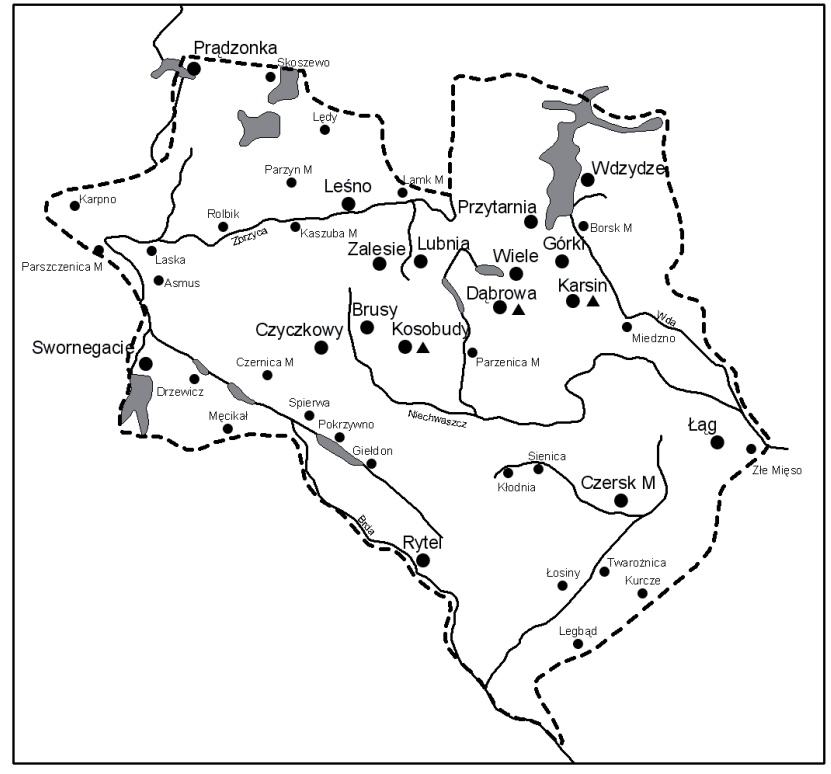

Figure 3. Settlement and economic units in the demesne of Zabory and the field demense in the 18th century (the source: Dygdała 2005, altered)

of the 18 th century was inhabited by 3,585 persons. Population density of the field demesne was significantly higher.

Despite the economic activity conducted here for already a long time, the region is characterized by significant naturalness of nature systems. The area of the former Zabory demesne includes considerable parts of the Zaborski Landscape Park and the Tuchola Forest National Park. Moreover, the north-eastern boundary of the Zabory demesne comprises a considerable part of the Wdzydzki Landscape Park and its south-eastern boundary runs through the Tuchola Landscape Park. Whereas, the field demesne encompasses some areas of the Tuchola Landscape Park in its eastern part and a small fragment of the Krajeński Landscape Park in its western part.

Forests are the dominating land cover form in all landscape parks. Forests within the Zabory demesne are mostly the property of the State Treasury and are subject to the authority of the Regional Directorate of State Forests (RDLP) in Torun (forest divisions: Przymuszewo, Rytel, Czersk, Woziwoda), RDLP in Szczecinek (the Forest Division of Osusznica) and RDLP in Gdańsk (forest divisions: Lipusz and Kościerzyna). State forests the Tuchola demesne are under the authority of RDLP in Torun (forest divisions: Woziwoda, Tuchola, Zamrzenica, Lutówko and Runowo).

In the demesne of Zabory, there are 11 nature reserves, including 8 reserves within the landscape parks. Within the field demesne, there are two nature reserves, one of which - the Brda River valley in the Tuchola Landscape Park - has the area of as much as 1,681.50 ha. Nearly the whole area of the Zabory demesne and a considerable part 
of the field demesne are included in the Natura 2000 Area of Tuchola Forest, created on the basis of the EU Birds Directive. Moreover, in both demesnes there are few Special Protection Areas Natura 2000, designated on the basis of the EU Habitat Directive. Almost the entire studied area, except for its western borderlands, was recommended to be included in the World Tuchola Forest Biosphere Reserve.

\section{Methods}

\subsection{Cartographic sources and forest inventory data processing}

Analysis of the biomass state and its depletion calculated in relation to potential state was performed in the GIS technology with the use of the programme ArcView by the company ESRI. The map by Schrötter-Engelhardt from the end of the 18th century (Zaborski 1932, 1935) was the main source of information on the vegetation cover in the study area in the past. When determining the boundaries and estimating the area of demesnes in the Tuchola starosty (district), the aforementioned maps by Biskup and Tomczak (1955), Mikulski (1994) and Dygdała (2005) were used. Topographic maps, forest economic maps and soil-habitat maps were applied in the analyses of contemporary states of land cover, biomass states and resources of organic carbon. When estimating the resources of potential biomass and organic carbon, the map of potential vegetation of Poland was used, drawn up by Matuszkiewicz et al. (1995).

The data necessary for calculating the forest biomass were obtained from appropriate Forest District Offices. The data, originally as a MS Access database, were exported as a table into MS Excel and compiled into useful tables in ArcMap, where each forest subdivision has the following parameters assigned: the area, the main species, its contribution, age, volume and site class.

This database required data handling in order to separate the necessary data and also to assign the right subarea for each tree species. The next step in the analysis was to segregate the data by species, age and site class in order to calculate the biomass using the conversional factors. This forest inventory computer database was used to calculate the current plant biomass. Areas of each forest habitat type, necessary for understory and forest floor estimation, were exported from the tables.

The data on the land cover were estimated in ArcMap, a GIS software from the ArcGIS 9.1 package. Based on eight topographical maps, a vector map of land cover in ArcMap was drawn. Moreover, the current forest use was updated by vector layers from Forest District Offices. The land cover was divided into basic categories, such as governmental and private forests, forest division lines, meadows, crops, heaths (if data were available), settlement and water areas.

\subsection{Assessment of the current aboveground biomass in the Tuchola Forest National Park and the Zaborski Landscape Park}

\subsubsection{Biomass of state forest}

The above-ground biomass for trees over 20 years old was calculated based on the data from the Forest Frame, where the area covered by each of the tree species and the timber volume in cubic meters could be found. Then, similarly to Johnson and Sharpe (1983), and Murillo-Rodriquez (1994, 1997), using the proportion of the total tree mass to usable timber mass $(\mathrm{T} / \mathrm{M})$ in a given tree stand, the total volume of a tree, usable timber and branches were calculated. T/M proportions were estimated on the basis of Szymkiewicz's tree volume and growth tables' compilation (Szymkiewicz 2001).

Having the volume of trees and multiplying it by specific gravity values from Krzysik (1978), the biomass of each tree was estimated. Biomass of needles in pine tree stands was calculated based on the weight of green biomass provided by Barcikowski (1992, 1996), as well as a percentage contribution of trees, herbaceous plants, mosses and lichens in that biomass in forest developmental series after regeneration of forest at logging sites on habitats of fresh and dry pine forest. For tree stands dominated by other species, $1.5 \%$ of wooden biomass was assumed as a foliage biomass of trees, according to Laurow (1966).

Since Szymkiewicz (2001) does not provide the branch volume for Larix europaea to estimate the biomass of this fraction, the empirical models proposed by Nishizono et al. (2005) for forest biomass of Larix kaempferi were used. Both species are so very similar, that even genetic markers are necessary to distinguish them (Jagielska 2008).

The biomass of branches is described by a linear equation as follows:

$$
Y=0.24 W_{S}^{0.79}
$$

where $Y$ is a biomass of branches per unit area [t/ha] and $W_{S}$ is stem biomass per unit area [t/ha] taken from Szymkiewicz's tree volume and growth tables, and calculated in the same way as for other tree species.

Biomass of foliage on large area was estimated by a stable equation:

$$
F=2.95
$$

where $F$ is a foliage biomass per unit area [t/ha].

Therefore, biomass of Larix europaea DC. per area unit [t/ha] is equal to:

$$
B_{\text {Lar }}=W_{S}+Y+F
$$

where $B_{\text {Lar }}$ is a tree biomass per unit area $[\mathrm{t} / \mathrm{ha}]$. 
Since juvenile trees, below 20 years old, are very dynamic, their biomass was calculated as one average value. In the Tuchola Forest, those juvenile tree stands consist mainly of Pinus sylvestris. A value for pine trees in age of 10 years was assumed in calculations. Having the dbh and the height of trees, we took the average size of pine trees and their average wood volume $\left(v=8 \times 10^{-4} \mathrm{~m}^{3} /\right.$ tree $)$ from tables produced by the Institute of Forest Research. The number of 10-year-old trees per hectare, i.e. parameter $k=9000$ trees/ha, was taken from Szymański (1970). The average volume of wood per 1 ha of pine monoculture was calculated as a quotient $v$ and $k$. Multiplying the obtained result by specific gravity of $0.49 \mathrm{t} / \mathrm{m}^{3}$ for pine wood (Krzysik 1978), the weight of wood was calculated per 1 ha of cultivation. The biomass of needles was added to wood biomass. It was calculated as a product of wood volume and weight of needles per unit of wood volume. Orzeł et al. (2005) quote that this last parameter has the value of $0.0193 \mathrm{t} / \mathrm{m}^{3}$.

Finally, the average biomass of pine trees per hectare of monoculture was obtained by the following equation:

$\left(8 \times 10^{-4} \mathrm{~m}^{3} /\right.$ tree $\times 9000$ trees $/$ ha $\left.\times 0,49 \mathrm{t} / \mathrm{m}^{3}\right)+$

$+\left(8 \times 10^{-4} \mathrm{~m}^{3} /\right.$ tree $\times 9000$ trees $/$ ha $\left.\times 0.193 \mathrm{t} / \mathrm{m}^{3}\right)=$

$=3.67 \mathrm{t} / \mathrm{ha}$

In order to assess the biomass of understory in fresh pine forest and dry pine forest habitats, we use the conservation factor of biomass, equal to $0,031 \mathrm{t} / \mathrm{ha}$ (Nienartowicz 2002). It was estimated empirically based on the density and the height of the common species Juniperus communis in tree stands of different age in different habitats and based on the relation between the height and the weight of each specimen. In the case of more fertile forest habitats, the biomass of $2.19 \mathrm{t} /$ ha calculated for the Niepołomice Primeval Forest (Puszcza Niepołomicka) (Orzeł et al. 2005) was being applied. For the estimation of above-ground biomass of forest ground cover in tree-stands from different habitats and of different age, values from the works of Dzięciołowski (1970), Kwiatkowska and Dudziec (1974), Barcikowski (1992, 1996) and Wilkoń-Michalska et al. (1998) were used. The last three studies were carried out in the Przymuszewo Forest District.

\subsubsection{Biomass of private forest and not-forest lands}

There are no data available for not state-owned forests to assess the biomass by the above described method, however their area was extracted in ArcMap. Because this forest category is a minority in both parks, we assumed the average biomass per hectare obtained for state-owned forests and this value was multiplied by the private forest area. Average values of above-ground biomass in the Przymuszewo Forest District and the Rytel Forest District,
141.84 and $167.53 \mathrm{t} /$ ha respectively, were used for this calculation. Those values were being used depending on a forest division within which an analyzed private forest was located.

The similar method was used for calculation of plant biomass of non-forest ecosystems. From the numerical land use map, worked out in ArcMap, the area of each non-forest land cover / land use category was obtained and was multiplied by the value of dry matter per ha. Values of above-ground plant biomass for forest division lines, farmlands, meadows, heathlands and settlement areas, i.e. 4.1, $10.0,20.5,6.77$ and $31.7 \mathrm{t} / \mathrm{h}$ a respectively, were taken from the work by Nienartowicz (1996) and Wilkoń-Michalska et al. (1998).

For aquatic ecosystems, the mean value of $1.76 \mathrm{t} / \mathrm{ha}$ was used. This value was obtained assuming after Rejewski (1981) that phytolittoral in the Tuchola Forest region covers $50.81 \%$ of the water area. Within the phytolittoral area, emergent macrophytes cover $23.18 \%$ and submerged macrophytes $-76.82 \%$. Rejewski (1981) also reported that plant biomass in the studied region amounts to $3.39 \mathrm{t} / \mathrm{ha}$ within the area covered by emergent macrophytes and $1.86 \mathrm{t} / \mathrm{ha}$ in the area covered by submerged macrophytes. Biomass of pelagic plankton algae $(0.38 \mathrm{t} / \mathrm{ha}$ of the water area), littoral plankton $(0.17 \mathrm{t} / \mathrm{ha})$ and periphyton $(0.08 \mathrm{t} / \mathrm{ha})$ was added to average biomass of both types of macrophytes per 1 ha of waters (i.e. $0.40 \mathrm{t} / \mathrm{ha}$ and $0.73 \mathrm{t} / \mathrm{ha}$ for emergent and submerged macrophytes respectively). The latter values were calculated based on the data on primary production $(\mathrm{P})$, the biomass state $(\mathrm{B})$ and the $\mathrm{P} / \mathrm{B}$ ratio of algae from different zones of lakes in the Tuchola Forest and the Iławskie Lake District in northern Poland. These data came from papers by Adamczak et al. (1979) and Oleksowicz (1980, 1986).

\subsubsection{Biomass of potential natural vegetation}

Potential biomass was estimated using a vector map of potential vegetation based on the potential natural vegetation map of Poland (Matuszkiewicz et al. 1995). This map was created based on the method described by Matuszkiewcz and Kozłowska (1981). The map of potential vegetation of the Tuchola Forest National Park and the Zaborski Landscape Park is presented in Figure 4. The area of each plant community type was extracted to the table by ArcMap.

In order to assess the biomass volume of mature forests on each habitat type, the average biomass per unit area was calculated for each forest association distinguished in the Matuszkiewicz's map of potential vegetation. The aforementioned method of biomass assessment was applied. The inventory data were taken from the Tuchola Forest National Park and from the Osie Forest District, included in the Tuchola Forest Promotion Complex, where plant associations for each subdivision were described together with 


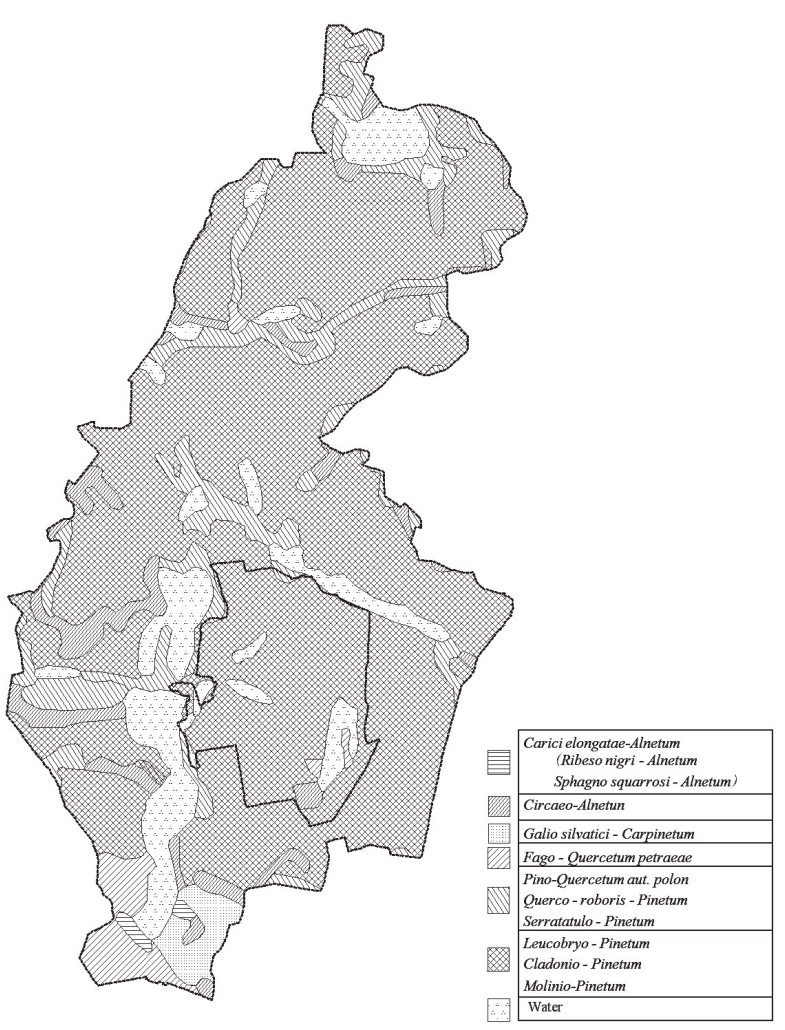

Figure 4. Potential vegetation in the Tuchola Forest National Park and the Zaborski Landscape Park

other characteristics in the database. Although the Osie Forest District is situated in the eastern part of the Tuchola Forest, the data from that forest complex are closely related to the whole region. To estimate the biomass of potential vegetation without human disturbance, tree stands of at least 80 years old were selected. The Table 1, presented below, contains the average biomass values obtained for each plant association, or their groups, distinguished in the Matuszkiewicz's potential vegetation map.

In the case of aquatic ecosystems, the conversion factor of $0.2 \mathrm{t} / \mathrm{ha}$ was applied for potential biomass. And thus, it was assumed that actual and potential biomass in areas covered by ecosystems of this type are identical.

\subsection{Current and potential above-ground biomass evaluation in the areas of the Zabory Demesne and the Tuchola Demesne}

Data obtained for the Tuchola Forest National Park and the Zaborski Landscape Park were interpolated (transferred) into a large area of the former Tuchola district (starosty). In this area of more than $1,700 \mathrm{~km}^{2}$ no such detailed analyses have been conducted like for the area of both parks. Evaluation of the biomass state in the forest area was carried out
Table 1. Above ground biomass of forest plant association with tree-stand age from 80 years

\begin{tabular}{|l|c|}
\hline \multicolumn{1}{|c|}{ Plant association } & $\begin{array}{c}\text { Average dry biomass } \\
\text { in } \mathrm{t} / \mathrm{ha}\end{array}$ \\
\hline $\begin{array}{l}\text { Ribeso nigri - Alnetum, } \\
\text { Sphagno squarrosi-Alnetum }\end{array}$ & 148.82 \\
\hline Circaeo - Alnetum & 152.78 \\
\hline Galio sylvatici - Carpinetum & 200.17 \\
\hline Fago - Quercetum petraeae & 183.37 \\
\hline $\begin{array}{l}\text { Querco - roboris - Pinetum, } \\
\text { Pino - Quercetum, } \\
\text { Serratatulo - Pinetum }\end{array}$ & 192.73 \\
\hline $\begin{array}{l}\text { Cladonio - Pinetum, Leucobryo } \\
\text { - Pinetum, Molinio - Pinetum }\end{array}$ & 179.36 \\
\hline
\end{tabular}

by the simplified method. It consisted in multiplying the total area of forests and surface division lines in each demesne by the amount of above-ground biomass (the total of the main tree layer, understory, undergrowth and herb layer) by an arithmetic average of biomass per unit area of state forests in the Zaborski Landscape Park. In the area of the former Tuchola district (starosty), likewise in the Zaborski Landscape Park, managed forests dominate. And thus in the analysis, no calculations were applied according to habitat types of forest, tree species, age of the main tree stand, syntaxonomic units or forest ownership.

In the case of non-forest ecosystems, the same conversion factors were applied like in the calculations of plant biomass in the Tuchola Forest National Park and the Zaborski Landscape Park.

The simplified calculation method was also applied for the evaluation of potential above-ground biomass. For the whole forest and non-forest terrestrial area, one quantity of $179.76 \mathrm{t} /$ ha was being applied. It was average potential biomass per unit area in the Zaborski Landscape Park and only slightly higher than potential biomass for fresh pine forest, and thus the dominant habitat, both in the landscape park and in the former Tuchola district (starosty). The same amount was applied for calculations carried out according 
to conditions from 1796 and 2008. Potential biomass of the area covered by aquatic ecosystems was calculated the same way as for the Tuchola Forest National Park and the Zaborski Landscape Park.

Potential biomass in the demesnes of Zabory and Tuchola was also calculated on the basis of surface area of particular habitat types read off from the potential vegetation map. The area was read off in the GIS technology after plotting the administrative boundaries of both demesnes on the potential vegetation map. The area of each category was mulitplied by a relevant quantity of biomass per 1 ha, selected from values included in Table 1.

\subsection{Loss of above-ground plant biomass and loss of carbon stock contained in this biomass}

The above-ground biomass loss was calculated as a difference between the amount of potential above-ground biomass, potentially available in a given ecosystem with no human activities and the amount of above-ground biomass that actually remains in that ecosystem, or in a substitute ecosystem replacing the previous one under current management practices. This parameter, expressed by tons of dry weight, was calculated by the following equation:

$$
B_{h}=B_{0}-B_{a}
$$

where $\mathrm{B}_{0}$ is dry potential vegetation and $\mathrm{B}_{\mathrm{a}}$ is dry biomass of current vegetation (above-ground biomass stock or above-ground standing crop).

The percentage of dry above-ground biomass loss $\left(\mathrm{B}_{\mathrm{h}} \%\right)$ was expressed as follows:

$$
B_{h} \%=\left[B_{h} / B_{0}\right] \times 100 \%
$$

Biomass is a part of the biosphere carbon cycle. Carbon from the atmosphere is converted into biological matter by photosynthesis. Carbon is released to the atmosphere as carbon dioxide $\mathrm{CO}_{2}$ during the combustion. It is assumed that the amount of carbon stored in dry plant biomass makes up ca. $50 \%$ of its total weight (Gert et al. 2003; Smith et al. 2003).

Therefore, the received dry plant biomass was multiplied by the conversion factor of 0.5 :

$$
B_{C}=B_{h} \times 0.5
$$

and the percentage of above-ground carbon stock loss was expressed as follows:

$$
B_{C} \%=\left[B_{h} / B_{0}\right] \times 0.5 \times 100 \%
$$

where 0.5 is the ratio of carbon share in dry plant biomass to the total weight of this biomass.

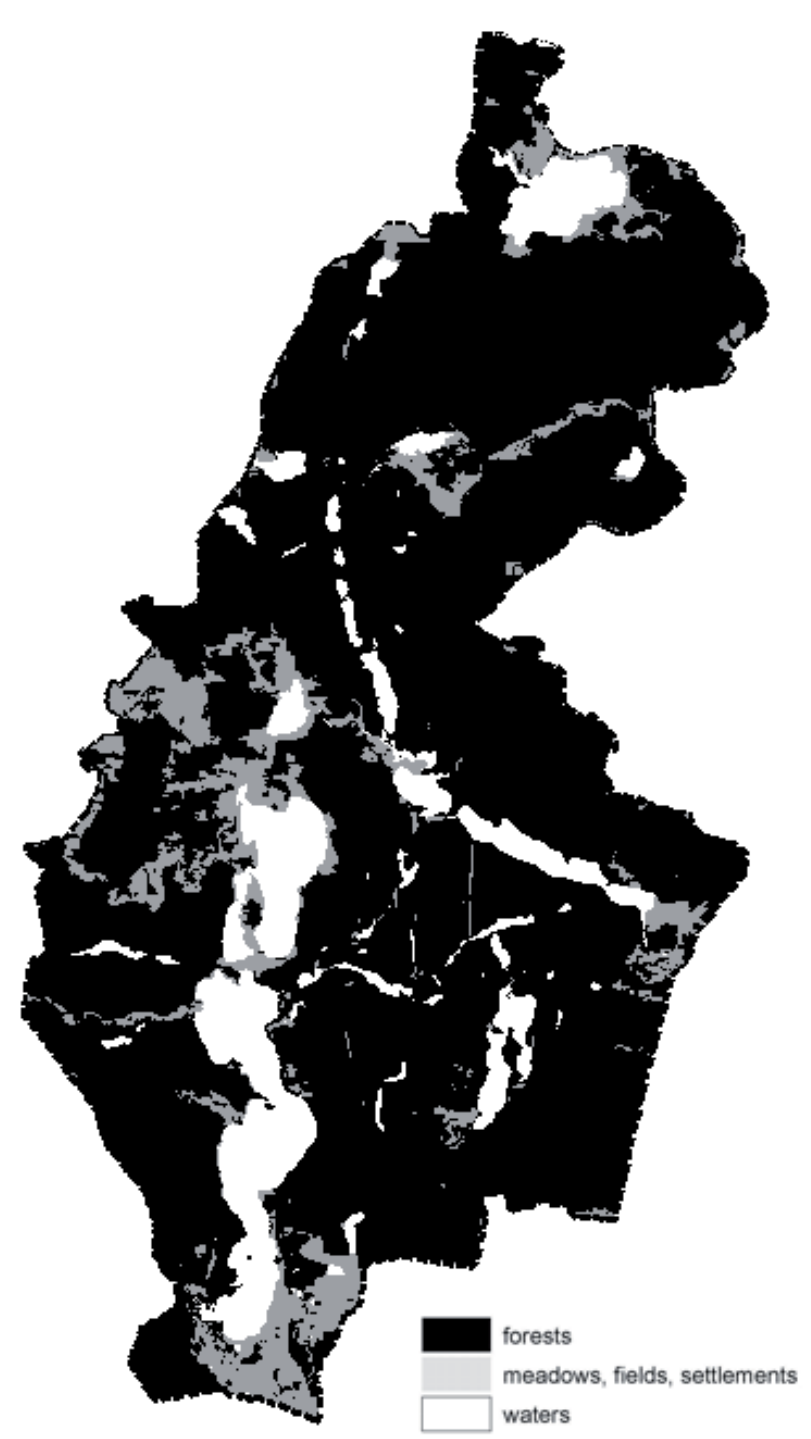

Figure 5. Land use/cover in the Tuchola Forest National Park and the Zaborski Landscape Park

\section{Results}

It was found in the analyses that in the territory of the Tuchola Forest National Park 526,191.14 t of dry aboveground plant biomass occurs. Applying the conversion factor of 0.5 , about $263,095.57 \mathrm{t}$ of carbon is present in that biomass. Plant biomass of forest ecosystems makes up ca. $99.22 \%$ of the total biomass. Certainly the predominance of forest biomass is due to the fact that forests situated to the east of Lake Charzykowskie, i.e. the national park location, cover relatively large areas (Fig. 5). As per unit of surface area, there are $114.07 \mathrm{t} / \mathrm{ha}$ in the whole Tuchola Forest National Park and $136.82 \mathrm{t} / \mathrm{ha}$ in its forest area.

The potential biomass in the National Park was assessed as 735,296.84 t. And thus, the actual biomass makes 
Table 2. The land use structure, the state of actual and potential biomass, as well as loss of biomass in the Tuchola Forest National Park and the Zaborski Landscape Park in 2008

\begin{tabular}{|c|c|c|c|c|}
\hline \multirow[b]{2}{*}{ Land-use form } & \multicolumn{2}{|c|}{ Tuchola Forest National Park } & \multicolumn{2}{|c|}{ Zaborski Landscape Park } \\
\hline & ha & $\%$ & ha & $\%$ \\
\hline Forests & $3,815.82$ & 82.72 & $23,544.45$ & 69.20 \\
\hline Waterbodies & 509.17 & 11.04 & $4,457.40$ & 13.10 \\
\hline Others & 172.58 & 3.74 & $1,066.13$ & 3.13 \\
\hline \multicolumn{5}{|l|}{ Including } \\
\hline Division lines, roads & 138.03 & 2.99 & $1,013.87$ & 2.98 \\
\hline Heaths & 34.55 & 0.75 & 52.26 & 0.15 \\
\hline Meadows, pastures & 93.36 & 2.02 & $1,633.25$ & 4.80 \\
\hline Fields, wastelands & 9.39 & 0.20 & $2,313.77$ & 6.80 \\
\hline Built-up areas & 12.72 & 0.28 & $1,011.00$ & 2.97 \\
\hline \multirow[t]{2}{*}{ Total } & $4,613.04$ & 100.00 & $34,026.00$ & 100.00 \\
\hline & \multicolumn{2}{|c|}{$\mathrm{t}$} & \multicolumn{2}{|c|}{$\mathrm{t}$} \\
\hline \multicolumn{5}{|l|}{ Actual vegetation } \\
\hline Forests & \multicolumn{2}{|c|}{$522,084.18$} & \multicolumn{2}{|c|}{$3,070,568.66$} \\
\hline Waterbodies & \multicolumn{2}{|c|}{896.14} & \multicolumn{2}{|c|}{$7,845.02$} \\
\hline Division lines, roads & \multicolumn{2}{|c|}{565.92} & \multicolumn{2}{|c|}{$4,075.77$} \\
\hline Heaths & \multicolumn{2}{|c|}{233.90} & \multicolumn{2}{|c|}{353.80} \\
\hline Meadows, pastures & \multicolumn{2}{|c|}{$1,913.88$} & \multicolumn{2}{|c|}{$33,481.62$} \\
\hline Fields, wastelands & \multicolumn{2}{|c|}{93.90} & \multicolumn{2}{|c|}{$23,137.70$} \\
\hline Built-up areas & \multicolumn{2}{|c|}{403.22} & \multicolumn{2}{|c|}{$32,048.70$} \\
\hline Total & \multicolumn{2}{|c|}{$526,191.14$} & \multicolumn{2}{|c|}{$3,171,511.27$} \\
\hline \multicolumn{5}{|l|}{ Potential vegetation } \\
\hline Terrestrial ecosystems & \multicolumn{2}{|c|}{$734,400.70$} & \multicolumn{2}{|c|}{$5,315,313.19$} \\
\hline Aquatic ecosystems & \multicolumn{2}{|c|}{896.14} & \multicolumn{2}{|c|}{$7,845.02$} \\
\hline Total & \multicolumn{2}{|c|}{$735,296.84$} & \multicolumn{2}{|c|}{$5,323,158.21$} \\
\hline \multirow[t]{2}{*}{ Difference } & & & & \\
\hline & & & & \\
\hline Loss of biomass & & & & \\
\hline The present biomass & & & & \\
\hline
\end{tabular}




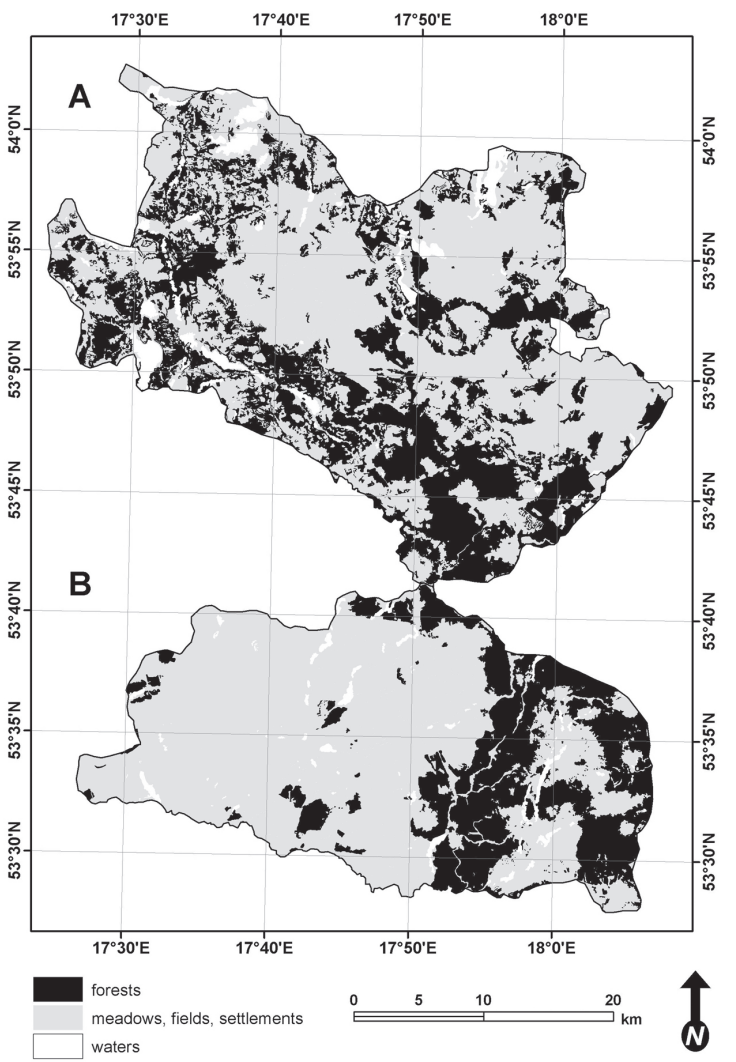

Figure 6. Distribution of forests and others forms of land cover/ use in the demesnes of Zabory (A) and Tuchola (B) in 1796

up $71.56 \%$ of the potential biomass, whereas the biomass loss brought about by human economic activity amounts to $28.44 \%$ (Tab. 2).

In the territory of the Zaborski Landscape Park, the above-ground plant biomass reaches 3,171,511.20 t. That biomass contains $1,585,755.64 \mathrm{t}$ of carbon. Similarly to the Tuchola Forest National Park, a considerable area in the surrounding landscape park is covered with forests (Fig. 2). Therefore, plant biomass of forest ecosystems makes up as much as $96.82 \%$ of the total biomass accumulated in the area of the Zaborski Landscape Park. The total plant biomass per unit of surface area amounts to $93.21 \mathrm{t} / \mathrm{ha}$ and $130.42 \mathrm{t} /$ ha in the case of forests.

The potential plant biomass in the Zaborski Landscape Park was assessed at 5,323,158.21 t, which makes up $156.44 \mathrm{t} / \mathrm{ha}$. The difference between the potential and actual biomass for the whole Landscape Park amounts to $2,151,646.94 \mathrm{t}$, whereas per unit of surface area - to 63.24 $\mathrm{t} /$ ha. The actual biomass makes up here $59.58 \%$ of the potential biomass, whereas the biomass loss induced by economic processes amounts to $40.42 \%$ (Tab. 2).

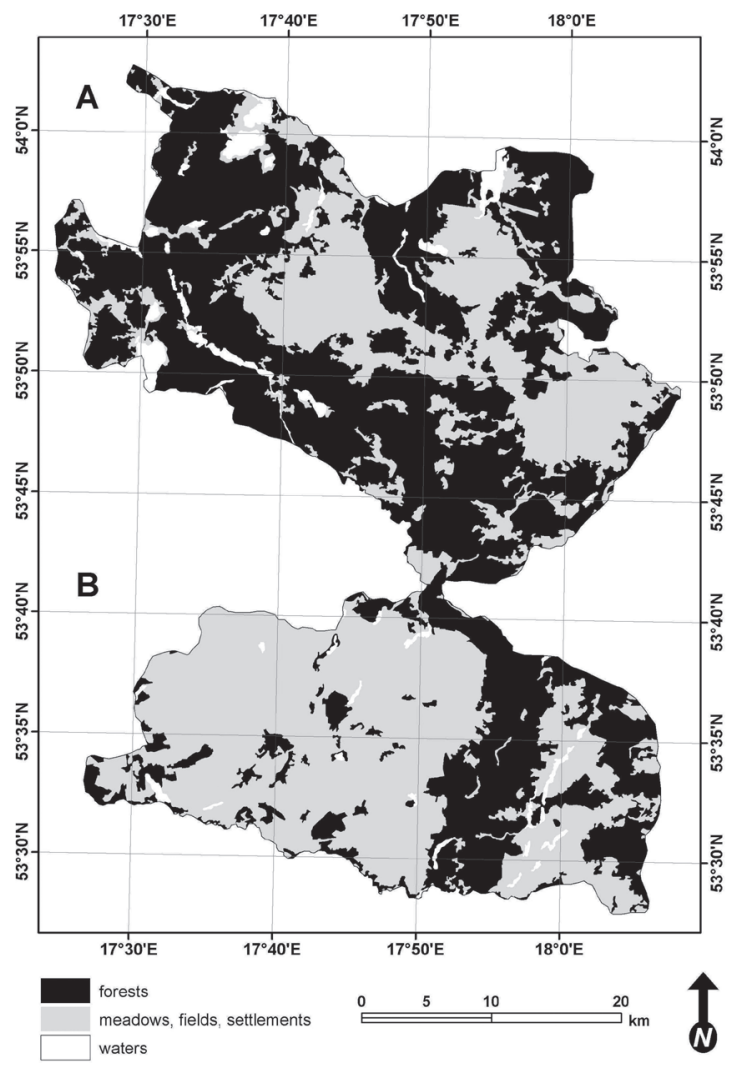

Figure 7. Distribution of forests and others forms of land cover/ use in the territory of the former demesne of Zabory and the demesne of Tuchola in 2008

It appears from the land cover structure of the Tuchola Starosty (district) that there are more forests in the demesne of Zabory than in the (field) demesne of Tuchola. Also in the demesne of Zabory, forests were more evenly distributed as compared to the demesne of Tuchola (Figs 6 and 7). Moreover, at present there are significantly more forests in this demesne than in 1796. In the demesne of Tuchola, after 212 years the forest area increased insignificantly.

Taking into account the land cover structure and applying indices of biomass per unit area of particular land cover categories, it was found that in the Zabory demesne there are at present 8,294,018.77 $\mathrm{t}$ of above-ground plant biomass and 3,332,512.23 $t$ in the demesne of Tuchola. In 1796 the biomass in the territory of those administrative and economic units amounted to 5,300,848.43 $\mathrm{t}$ and 3,013,157.70 t respectively. When comparing the biomass state during the studied periods, it was found that the increase of biomass between 1796 and 2008 amounted to 2,993,170.34 t in the demesne of Zabory and 319,354.53 $t$ in the demesne of Tuchola. This increase calculated per carbon amounts to $1,496,585.17 \mathrm{t} C$ in the former demesne and 159,677.26 t C 
Table 3. The land use structure, the state of actual and potential biomass, as well as loss of biomass in the demesnes of Zabory and Tuchola in 1796 and 2008

\begin{tabular}{|c|c|c|c|c|c|c|c|c|}
\hline \multirow{3}{*}{ Land-use form } & \multicolumn{4}{|c|}{ Demesne of Zabory } & \multicolumn{4}{|c|}{ Demesne of Tuchola } \\
\hline & \multicolumn{2}{|l|}{1796} & \multicolumn{2}{|c|}{2008} & \multicolumn{2}{|c|}{1796} & \multicolumn{2}{|c|}{2008} \\
\hline & ha & $\%$ & ha & $\%$ & ha & $\%$ & ha & $\%$ \\
\hline Forests & $36,067.80$ & 35.81 & $62,480.02$ & 62.04 & $18,903.21$ & 25.91 & $21,440.90$ & 29.39 \\
\hline Waterbodies & $4,624.80$ & 4.59 & $4,894.47$ & 4.86 & $1,736.89$ & 2.38 & $1,750.87$ & 2.40 \\
\hline Others & $60,016.65$ & 59.60 & $33,334.76$ & 33.10 & $52,312.96$ & 71.71 & $49,761.29$ & 68.21 \\
\hline \multicolumn{9}{|l|}{ Including } \\
\hline Meadows, pastures & $15,455.75$ & 15.35 & $8,831.34$ & 8.77 & $10,110.89$ & 13.89 & $7,283.12$ & 9.98 \\
\hline Fields, wastelands & $43,474.02$ & 43.17 & $22,086.40$ & 21.93 & $41,192.50$ & 56.46 & $38,961.83$ & 53.41 \\
\hline Built-up areas & $1,086.88$ & 1.08 & $2,417.02$ & 2.40 & $1,009.57$ & 1.39 & $3,516.34$ & 4.82 \\
\hline \multirow[t]{2}{*}{ Total } & $100,709.25$ & 100.00 & $100,709.25$ & 100.00 & $72,953.06$ & 100.00 & $72,953.06$ & 100.00 \\
\hline & \multicolumn{2}{|l|}{$\mathrm{t}$} & \multicolumn{2}{|l|}{$\mathrm{t}$} & \multicolumn{2}{|l|}{$\mathrm{t}$} & \multicolumn{2}{|l|}{$\mathrm{t}$} \\
\hline \multicolumn{9}{|l|}{ Actual vegetation } \\
\hline Forests & \multicolumn{2}{|c|}{$4,506,671.61$} & \multicolumn{2}{|c|}{$7,806,878.50$} & \multicolumn{2}{|c|}{$2,361,956.09$} & \multicolumn{2}{|c|}{$2,679,040.46$} \\
\hline Waterbodies & \multicolumn{2}{|c|}{$8,139.65$} & \multicolumn{2}{|c|}{$8,614.27$} & \multicolumn{2}{|c|}{$3,056.93$} & \multicolumn{2}{|c|}{$3,081.53$} \\
\hline Meadows, pastures & \multicolumn{2}{|c|}{$316,842.87$} & \multicolumn{2}{|c|}{$181,042.47$} & \multicolumn{2}{|c|}{$207,273.24$} & \multicolumn{2}{|c|}{$149,303.96$} \\
\hline Fields, wastelands & \multicolumn{2}{|c|}{$434,740.20$} & \multicolumn{2}{|c|}{$220,864.00$} & \multicolumn{2}{|c|}{$411,925.00$} & \multicolumn{2}{|c|}{$389,618.30$} \\
\hline Built-up areas & \multicolumn{2}{|c|}{$34,454.10$} & 76,6 & .53 & 32,0 & .37 & 111,46 & .98 \\
\hline Total & $5,300,84$ & 8.43 & $8,294,0$ & 3.77 & $3,013,1$ & .70 & $3,332,51$ & .23 \\
\hline Potential vegetation & & & & & & & & \\
\hline Terrestrial ecosystems & $17,272,14$ & 0.73 & $17,223,6$ & 1.85 & $12,801,8$ & 72 & $12,799,30$ & 67 \\
\hline Aquatic ecosystems & 8,13 & 9.65 & 8,6 & 1.27 & 3,0 & .93 & 3,08 & .53 \\
\hline Total & $17,280,28$ & 0.38 & $17,232,2$ & .12 & $12,804,8$ & 65 & $12,802,38$ & .20 \\
\hline Difference & $11,979,43$ & 1.95 & $8,577,7$ & .64 & $9,791,7$ & .95 & $9,469,87$ & .97 \\
\hline & $\%$ & & $\%$ & & $\%$ & & $\%$ & \\
\hline Loss of biomass & & 9.32 & & .87 & & .47 & & .97 \\
\hline The present biomass & & 0.68 & & 3.13 & & .53 & & .03 \\
\hline
\end{tabular}


in the latter one. The amount of carbon accumulated in the above-ground plant biomass in both demesnes during both studied periods is presented in Table 3.

As per unit of surface area, the biomass in the demesnes of Zabory and Tuchola amounted in 2008 to $82.36 \mathrm{t} / \mathrm{ha}$ and $45.68 \mathrm{t} /$ ha respectively. In 1796 it amounted to $52.64 \mathrm{t} / \mathrm{ha}$ in the demesne of Zabory and $41.30 \mathrm{t} / \mathrm{ha}$ in the demesne of Tuchola.

The potential above-ground biomass in the demesne of Zabory was assessed at $17,232,279.12 \mathrm{t}$, that is $171.11 \mathrm{t} / \mathrm{ha}$. The potential biomass in the field demesne was assessed at $12,802,387.20 \mathrm{t}$, what per unit area gave the value of $175.49 \mathrm{t} / \mathrm{ha}$. The loss of plant biomass in the demesne of Zabory, calculated in relation to potential biomass, amounted to $69.32 \%$ in 1796 and $51.87 \%$ in 2008 . The biomass loss in the demesne of Tuchola amounted to $76.47 \%$ and $73.97 \%$ in 1796 and 2008 respectively.

\section{Discussion and conclusions}

The state and the loss of plant biomass in the four studied objects were assessed with different accuracy. Those parameters were most precisely assessed in the smallest one, i.e. in the Tuchola Forest National Park. High accuracy of calculations for the National Park was achieved due to the fact that the complete inventory data are available for this Park, which describe each forest subdistrict and each division of other land use forms. These data were collected long before the Park was created, at the time when the area belonged to the Forest Division of Klosnowo and at present, when the area is under the direct authority of the Ministry of the Environment, they are collected when the conservation plan for the National Park is being prepared and updated. Higher accuracy of calculations for the National Park results also from the dominating land tenure. The State is the owner of $99.70 \%$ of the area here. In Poland, very detailed natural and economic inventories were being compiled for this land tenure, especially in the forest areas. In the Tuchola Forest National Park, there are only few areas of private and public property, merely 0.25 and $0.05 \%$ respectively (ZPK 2009, http://www.zaborypark. eco.pl). In the former case, those are mainly meadows, whereas in the latter case - unsurfaced roads, where there is no much plant biomass.

In the Zaborski Landscape Park, the percentage share of other land tenure forms, other than State property, is higher as compared to the National Park. However, also in this natural and economic object, forests are the dominating land cover form, the majority of which are state-owned. Starting from the end of the 19th century, the detailed inventorying has been carried out in those forests, regarding the types of habitats, species composition and age of tree stands, as well as the reserves and the increase of biomass.

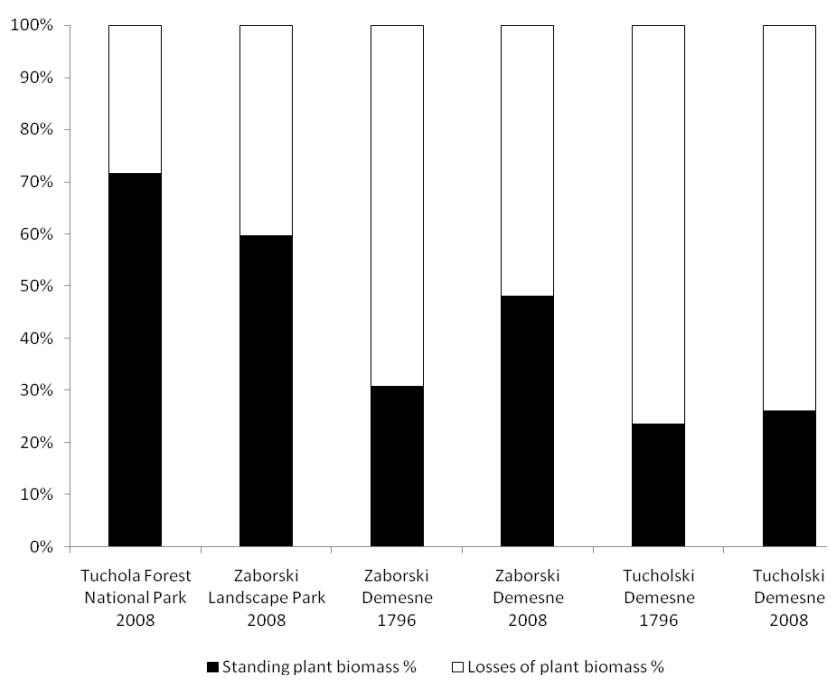

Figure 8. Comparison of actual biomass and biomass loss in relation to potential biomass in the studied objects

These data are being enriched with information regarding the undergrowth and plant species occurring in the herb layer. In the analyses performed within the scope of the present paper, the most recent inventory data were used, which also increases the accuracy of the actual biomass evaluation.

In the case of the Zabory and Tuchola demesnes, the evaluation of the state and depletion of the above-ground plant biomass is burden with the biggest error. It results from the fact that in these cases, no forest inventory data were used. Moreover, in this area of the research, there are many different land tenure forms and the access to data describing particular land divisions is impossible in many cases. In this situation, in order to assess the order of magnitude of the biomass loss, the simplified method of conversion factors was applied, with factors expressing the biomass state in individual types of ecosystems or developmental phases of forests.

The majority of the data, especially biomass conversion factors applied in the calculations, came from the Zaborski Landscape Park and the neighbourhood of the Tuchola Forest National Park. In the latter Park, biomass samples were not collected due to the high status of its legal protection. In only few cases there were applied conversion factors defined by other authors in other regions of Poland. This mainly concerns the herb layer of humid forests, particularly alder swamp woods and riverine forests. In the studied territories, habitats of fresh and dry pine forests covered the largest areas. And thus, the influence of humid deciduous forests on the general state of above-ground plant biomass was lower as compared to ecosystems of coniferous forests. Most of the conversion factors that we applied in order to assess the biomass states in the Tuchola 
Forest was obtained by research teams from the Nicolaus Copernicus University within the scope of the International Biological Programme (IBP) implemented in the seventies within the same region, as well as Polish governmental programmes R.III.15 and CPBP.04.10 in the eighties. In the face of climatic changes, which most probably influence the primary production, biomass state and carbon accumulation in plant biomass, it is worth to continue the research, expanding it into the forest ecosystems, which due to a lower contribution in the Tuchola Forest region, so far have not been investigated in detail yet. The research could also be steered onto the determination and evaluation of the carbon content in the biomass of different species of trees, herbaceous plants, mosses and lichens, so not only the general conversion factor of 0.5 would be applied in evaluations of the carbon accumulation in plant biomass of the Tuchola Forest.

The conducted research revealed that in areas of high protection status, such as the National Park with a high contribution of forests, the loss of plant biomass, calculated in relation to potential biomass, is small and it reaches just $30 \%$. It is mainly caused by a small extent of deforestation, i.e. replacing the forest ecosystems with meadows, arable fields, as well as housing estate areas and roads connecting the housing developments in the Park and outside the Park. In the forest areas, the loss is induced by exploitation of forest ecosystems in the past, that is before the National Park was created. Before 1996, in the territory of the present-day Tuchola Forest National Park, clear felling was being applied on a large scale for wood acquisition. In the subsequent years, this method was abandoned, however young growths and pine pole woods are still quite frequent here.

In the area of the Zaborski Landscape Park economic forests dominate. Wood logging still takes place here, although less intensively during last several years. Areas of clear felling was restricted and clusters of old trees were left at logging sites. And thus, the continuity of ecosystems is preserved to a certain extent. As it was mentioned in the description of the study area, at the end of the 19th century considerable areas of the park, nowadays covered with forests, were then covered with heaths and poor xerothermic meadows. They were exploited as sheep grazing lands, because sheep farming was well-developed here before the period of forest reconstruction. Within the scope of the Kulturkampf policy, implemented by the Prussian government of the chancellor Bismarck, the indebted Polish landed estates were being taken over and afforested together with repurchased Prussian estates. Forestliche Zwanshof was one of the bigger Prussian forest divisions, created in the territory of former landed estates.

Further afforestation in the northern part of the Zaborski Landscape Park and over fairly large areas of the whole Zabory demesne took place after the 1st World War, when forests of Gdańsk Pomerania - a former province of Western Prussia - were taken over by the Polish forest administration. At that time, in the territory of the former Forest Division of Zwangshof, the Polish Forest Division of Przymuszewo was created.

The subsequent, third period of afforestation comprised a few years after the 2nd World War, during which time, within the scope of the so-called agricultural reform, implemented by the Communist Government of Poland, quite a few former large landed estates were nationalized, taken over by state forests and then afforested. Also during the last several years, quite many agricultural areas were afforested. It took place in areas where soils were degraded, or where agriculture was abandoned due to unprofitability of farming on a small acreage of plots leased from state forests. Reconstruction of forests in agriculturally used areas, which was carried out in four aforementioned periods, brought about a significant decrease in the plant biomass loss in the area of the Zabory demesne, that is from $69.32 \%$ in 1796 to $51.87 \%$ in 2008 (depletion by $17.45 \%$ ).

In the field demesne, changes in the range of forests during the last 212 years were not so significant as in the forest demesne. Major afforestation occurred here after the 1st World War and in recent years, as a consequence of forest reconstruction and afforestation of wastelands. Therefore, only a decrease in depletion by $2.50 \%$ was recorded here.

The value of the above-ground plant biomass loss equal to $68.12 \%$, obtained in our studies for the Zabory demesne (forest) in 1796, is very similar to the value quoted for contemporary Austria. Haberl et al. (2001) reports that the above-ground standing crop (biomass stock) of the vegetation prevailing today is $\sim 64 \%$ lower than that of the potential vegetation. Whereas Erb (2004) stated that in the whole territory of this country, the present above-ground plant biomass contains $64 \%$ less carbon than it would be expected in the potential vegetation.

Large biomass losses in the vegetation cover occurs especially when one land use form is replaced another, like a forest by agricultural lands. Titlyanova and Kosykh (2000) report that within the forest-steppe zone in Siberia, the maximum phytomass in meadows amounts to $6 \mathrm{t} / \mathrm{ha}$. If the average biomass of forests occurring there before cutting them down is estimated after Whittaker (1975) at $200 \mathrm{t} / \mathrm{ha}$, the decrease is more than 33 times. And the other way around, reconstruction of forests over large, formerly arable lands, brings about a decrease in the biomass loss. Effects of such actions are reported by e.g. Johnston et al. (1996) from the State of Minnesota, USA, where forest plant communities spontaneously regenerate in fallow lands for 40 years. The phytomass increased there almost fivefold, from ca. $4.2 \mathrm{t} /$ ha in 1938 to $20.4 \mathrm{t} /$ ha in 1977 . In the analyses performed within the scope of the quoted paper, similarly like in our paper, the GIS technology as well 
as historical and contemporary cartographic materials were being applied on a large scale.

The average state of potential biomass in terrestrial ecosystems of the Zaborski Landscape Park obtained in our research, that is $209.02 \mathrm{t} / \mathrm{ha}$, is slightly higher than the value of $200 \mathrm{t} / \mathrm{ha}$ quoted by Whittaker (1975). If we assume that the above-ground biomass in forest ecosystems makes up $86 \%$ of the total biomass, the potential aboveground biomass for the studied Landscape Park and the average actual state of above-ground biomass for forests of the temperate zone amount to $179.76 \mathrm{t} / \mathrm{ha}$ and $172 \mathrm{t} / \mathrm{ha}$ respectively.

In the research on human effects on the nature, carried out within the scope of the present paper, phytomass was the measured value. Meantime, in many studies concerning the man - nature relationship, the most frequently evaluated parameter is the change of above-ground or both above-ground and underground primary production. Primary production is the main parameter, for instance, in the evaluation of changes in the functioning of ecosystems done by the method proposed by Vitousek et al. (1986, 1997), as well as in the assessment of HANPP worked out by the team of Prof. Helmut Haberl (Haberl et al. 2001, 2002, 2007a, b; Weisz et al. 2001; Erb et al. 2007). However, we believe that plant biomass accumulated in a given ecosystem is a significant element, which defines its state. Because primary production could be similar in so different ecological systems, such as field and forest, whereas the level of their phytomass is usually very different. It is even better when both parameters are defined, because it is possible then to determine the so-called negentropic cost, which expresses the intens ity of solar energy fixation in primary production and the magnitude of energy expenses per unit of plant biomass accumulated in an ecosystem. This index, proposed by Giampietro and Pimentel (1991), as well as Giampietro et al. (1992), allows to assess whether an ecological system of different naturalness extent is exploited in accordance with the principles of eco-development, or its exploitation by man is too intensive.

In order to increase the accuracy of the evaluation of plant biomass and the content of carbon, particularly in historical states, it is also necessary to specify more precisely the notions of the past and the present natural potential vegetation, and to determine more precisely the final developmental states in different periods of the history and further development of the studied ecological system. In the present paper, in order to determine the potential biomass for two different developmental states of the Zabory and Tuchola demesnes, the same categories of land cover were assumed and the same maps of potential vegetation were used. Probably one should assume categories of potential vegetation that contemporary existed during a given investigated period (i.e. contemporary potential natural vegetation). It was done by Łaska (2007) in the research on the extent of transformations caused by human management in the structure of forest plant communities in the Knyszyn Forest (Puszcza Knyszyńska) in north-eastern Poland.

In the present paper only plant biomass was estimated. However, the developed system of information on changes in the land use structure and individual indices of biomass in different types of ecosystems, enriched with indices of the rate of biomass formation and its decomposition, could be a starting point, not only for carbon accumulation in the above-ground biomass, but also in the underground and the total biomass, as well as in the soil. Enrichment of the analysis with further indices, as well as skilful application of forest inventory data and Land Cover maps will enable an objective evaluation of plant biomass and carbon accumulated in large regions.

\section{Acknowledgements}

This paper was prepared within the framework of research on potential possibilities of fixation and accumulation of carbon in plant biomass - the research grant by MNiSW (Ministry of Science and Higher Education) no. N N305 336834 ,Current and potential resources of organic carbon in the landscape of Tuchola Forest".

\section{References}

Adamczak B., Luścińska M., Oleksowicz A.S. \& Rejewski M., 1979, The primary production of the lake Tynwałd, Acta Univ. Nicolai Copernici, Limnological Papers 11: 3-9.

Barcikowski A., 1992, Differentiation in the structure and energy flow in phytocenoses with primary and secondary succession, [in:] R. Bohr, A. Nienartowicz, J. Wilkoń-Michalska (eds.), Some ecological processes of the biological systems in North Poland, Nicolaus Copernicus University Press, Torun: 35-58.

Barcikowski A., 1996, Biomass and chlorophyll of photosynthesizing organs of plant communities in secondary succession in pine forest habitat, Photosynthetica 32(1): 63-76.

Barcikowski A. \& Loro P., 1993, Straty w produkcji pierwotnej brutto ekosystemów leśnych wywołane zabiegami gospodarczymi w aspekcie "efektu cieplarnianego" [Losses in gross primary production of forest ecosystems due to man'seconomic activity in the aspect of the „greenhouse effect”, [in:] M. Rejewski, A., Nienartowicz, M. Boiński (eds.), Bory Tucholskie: Walory przyrodnicze - problemy ochrony - przyszłość (materiały pokonferencyjne) [Tuchola Forests: Natural value - 
Conservation problems - Future (post-conference papers) Wyd. UMK, Toruń: 270-282.

Barcikowski A. \& Loro P., 1995, Biomasa igliwia oraz cech dendrometryczne samosiewów sosny (Pinus sylvestris L.) młodszych klas wieku, rozwijającej się na siedlisku boru świeżego [Needle biomass and dendrometrical features of Scots pine (Pinus sylvestris L.) natural regeneration seedlings of younger age classes, growing on a fresh coniferous forest site], Sylwan CXXXIX(2): 53-62.

Biskup M. \& Tomczak A., 1955, Mapy województwa pomorskiego w drugiej połowie XVI w., I. Rozmieszczenie własności ziemskiej, II. Sieć parafialna [Maps of the Pomerania province in the latter half of the 16th century, I. Distribution of land ownership, II. Parish network], Roczniki Towarzystwa Naukowego w Toruniu 58(1): 1-180.

Crumley C. L, 1993, Historical Ecology: Cultural Knowledge and Changing Landscapes, Santa Fe, NM.

Deptuła M., 2006, Influence of the past economy on the structure, carbon accumulation and species diversity of forest tree stands and phytocenoses, Ecological Questions 7: 57-68.

Dygdała J., 2005, Lustracja województw Prus Królewskich 1765, t. I: Województwo pomorskie, cz. 3: Powiaty świecki, tucholski i człuchowski [Inspection of provinces in Royal Prussia 1765, vol. I: the Pomerania province, part 3: Poviats (districts) of Świecie, Tuchola and Człuchów], TNT Fontes 94, Wyd. UMK, Toruń.

Dzięciołowski R., 1970, Biomasa runa leśnego oraz podszytów jako potencjalna baza pokarmowa zwierząt roślinożernych [Biomass of herb layer and understorey plants as potential food resources for herbivorous animals], Fol. Forest. Pol., Ser. A, Leśnictwo 16: 69-90.

Dzięciołowski R., 1971, Sytuacja troficzna populacji jeleni W zależności od warunków środowiskowych [Trophic situation of deer populations in relation to environmental conditions], PWRiL, Warszawa.

Erb K.-H., 2004., Land-use related changes in aboveground carbon stocks of Austria's terrestial ecosystems, Ecosystems 7: 563-572.

Erb K.-H., Gingrich S., Krausmann F. \& Haberl H., 2008, Industrialization, fossil fuels, and the transformation of land use: An Integrated Analysis of Carbon Flows in Austria 1830-2000, Journal of Industrial Ecology 12 (5/6): 686-703.

Gert J. N., Schedelhass M. J., Mohrens G. \& Field Ch. B., 2003, Temporal evolution of the European forest sector carbon sink from 1950 to 1999 , Global Change Biology 9: 152-160.

Giampietro M., Cerretelli G. \& Pimentel D., 1992, Energy analysis of agricultural ecosystem management: $\mathrm{Hu}-$ man return and sustainability, Agriculture, Ecosystems and Environment 38: 219-244.

Giampietro M. \& Pimentel D., 1991, Energy analysis models to study the biophysical limits for human exploitation of natural processes, [in:] C. Rossi, E. Tiezzi (eds.), Ecological Physical Chemistry, Proceedings of an International Workshop, 8-12 November 1990, Siena, Italy: $139-184$.

Gingrich S., Erb K.-H., Krausmann F., Gaube V. \& Haberl H., 2007, Long-term dynamics of terrestrial carbon stocks in Austria: a comprehensive assessment of the time period from 1830 to 2000, Reg. Environ Change, DOI 10.1007/s10113-007-0024-6.

Haberl H., Erb K-H. \& Krausmann F., 2007a, Human Appropriation of net primary production (HANPP), Institute of Social Ecology, Klagenfurt University Vienna, Austria, Retrieved from: Internet Encyclopaedia of Ecological Economics http://www.ecoeco.org/publica/ encyc.htm at 15 December 2008.

Haberl H., Erb K.-H., Krausmann F., Gaube V., Bondeau A., Plutzar Ch., Gingrich S., Lucht W. \& Fischer-Kowalski M., 2007b, Quantifying and mapping the human appropriation of net primary production in earth's terrestrial ecosystems, The National Academy of Sciences of the USA 104(31): 12942-12947.

Haberl H., Erb K-H., Krausmann F., Loibl W., Schulz N. \& Weisz H., 2001, Changes in ecosystem process induced by land use: Human appropriation of aboveground NPP and its influence on standing crop in Austria, Global Biogeochemical Cycles 15(4): 929-942.

Haberl H. \& Geissler S., 2000. Cascade utilization of biomass: strategies for a more efficient use of a scarce resource, Ecological Engineering 16: 111-121.

Haberl H., Krausmann F., Erb K.-H. \& Schulz N. B., 2002, Human Appropriation of Net Primary Production, Science 14 June 2002 (296): 1968-1969.

Jagielska A., 2008, Zastosowanie markerów genetycznych w identyfikacji gatunkowej modrzewia europejskiego (Larix decidua Mill.) i japońskiego (Larix kaempferi Sorg.) oraz ich mieszańców [Application of genetic markers in species identification of European and Japanese larch and their hybrids], Leśne Prace Badawcze [Forest Research Papers] 69(1): 21-25.

Johnson A. W. \& Earle T., 1987, The Evolution of Human Societies: From Foraging Group to Agrarian State, Stanford, CA.

Johnson W. C. \& Sharpe D. M., 1982, The ratio of total to merchantable forest biomass and its application to the global carbon budget, Can. J. For. Res. 13: 372-383.

Johnston M. H., Homann P. S., Engstrom J. K. \& Grigal D. F., 1996, Changes in ecosystem carbon storage over 40 years on an old-field/forest landscape in east-central Minnesota, Forest Ecology and Management 83: $17-26$. 
Kratochwil Z., 1981, Klucz zaborski w komturstwie tucholskim i starostwie tucholskim w latach 1330-1772 [The Teutonic Commanders' Demesne and Starosty Demesne, Zabory - in Tuchola Land, during 1330-1772], Rocznik Gdański XLI, 1981(1): 89-131.

Krzysik F., 1978, Nauka o drewnie [Wood science], PWN, Warszawa.

Kwiatkowska A. J. \& Dudziec J., 1974, Zmienność przestrzenna stanu biomasy części nadziemnej runa w rezerwacie Grabowy w Puszczy Kampinoskiej [Spatial variability of the state biomass of the above-ground part of the field layer in the "Grabowy" reservation of the Kampinos Forest], Phytocoenosis 3(1/2): 43-68.

Kunz M., Nienartowicz A., Deptuła M., 2000, The use of satellite remote sensing imagery for detection of secondary forests on post-agricultural soils: A case study of Tuchola Forest, Northern Poland, [in:] J. L. Casanova (ed.), Remote Sensing in the 21st Century. Economic and Environmental Applications, Proceedings of the 19th EARSeL Symposium on Remote Sensing in the 21st Century/Valladolid/Spain/31 May - 2 June 1999, A.A. Balkema/Rotterdam/Blookfield: 61-66.

Laurow Z., 1966, Kompleksowe użytkowanie arbomasy [Comprehensive exploitation of arbomass], Wyd. Swiat, Warszawa.

Lieth H., 1975, Primary productivity of the major vegetation units of the world, [in:] H. Lieth, R. H. Whittaker (eds.), Primary productivity of biosphere, Ecol. Stud. 14, Springer - Verlag, New York: 203-231.

Łaska G., 2007, Tendencje dynamiczne zbiorowisk zastępczych w Puszczy Knyszyńskiej [Dynamic tendencies of the secondary communities in the Knyszyńska Forest], Bogucki Wyd. Naukowe, Poznań.

Matuszkiewicz J. M. \& Kozłowska A. B., 1981, Założenia teoretyczne, metody i technika wykonywania przeglądowej mapy potencjalnej roślinności naturalnej (na przykładzie badań fizjologiczno-kartograficznych na Wysoczyźnie Siedleckiej) [Grundsätze, Methoden und Kartierungsverfahren der Übersichtskarte der poteniell natürlichen Vegetation (am Beispiel einer Vegetationskartierung im Naturraum „Wysoczyzna Siedlecka” d.h. „Landrücken von Siedlce” im Ostpolen], Fragm. Flor. Geobot. XXVI(1-2): 171-211.

Matuszkiewicz W., Faliński J. B., Kostrowicki A. S., Matuszkiewicz J. M., Olaczek R. \& Wojterski T. (eds.), 1995, Potencjalna roślinność naturalna Polski, mapa przeglądowa 1:300 000 [Potential natural vegetation of Poland. General map 1 : 300,000], Polska Akademia Nauk, Instytut Geografii Przestrzennego Zagospodarowania, Wojskowe Zakłady Kartograficzne, Warszawa.

Mikulski K., 1984, Osadnictwo wiejskie województwa pomorskiego od połowy XVI do końca XVII wieku [Ländliches Siedlungswesen in der Pommerellischen
Wojewodschaft von der Mitte des 16. bis Ende des 17. Jh.], Roczniki Towarzystwa Naukowego w Toruniu 86(2): 1-214.

Murillo-Rodriquez J. C., 1994, The carbon budget of the Spanish forests, Biochemistry 34: 1-21.

Murillo-Rodriquez J. C., 1997, Temporal variations in the carbon budget of forest ecosystems in Spain, Ecological Applications 7(2): 461-469.

Nienartowicz A., 1992, Man's energy impact to the formation and functioning of landscape, [in:] R. Bohr, A. Nienartowicz, J. Wilkoń-Michalska (eds.), Some ecological processes of the biological systems in North Poland, Nicholas Copernicus University Press, Torun: 17-33.

Nienartowicz A., 1993, Metabolizm kulturowy na wybranych obszarach Zaborskiego Parku Krajobrazowego [Culture metabolizm of selected areas of Zaborski Landscape Park], [in:] M. Rejewski, A. Nienartowicz, M. Boiński (eds.), Bory Tucholskie: Walory przyrodnicze - problemy ochrony - przyszłość (materiały pokonferencyjne) [Tuchola Forests. Natural Value - Conservation Problems - Future (post-conference papers)], Wyd. UMK, Toruń: 305-328.

Nienartowicz A., 1996, Energetyka dużych systemów ekologicznych [Energetics of large ecological systems], Wyd. UMK, Torun.

Nienartowicz A., 1999, Zastosowanie metod energetyki ekologicznej do oceny ekorozwoju na obszarach leśnych [The application of ecological energetics methods for quantification of sustainability in forest areas], [in:] A. Barcikowski, M. Boinski, A. Nienartowicz (eds.), Wielofunkcyjna rola lasu: Ochrona przyrody - Gospodarka - Edukacja, IV Konferencja Naukowa w Borach Tucholskich [Multifunctional role of forest: Protection of Nature - Economy - Education, IV Scientific Conference in Tuchola Forest], Toruń - Funka 7 - 10.10.1999, UMK, O.W. „TURPRESS”, Toruń: 111-121.

Nienartowicz A., 2002, Energetyczny bilans zagospodarowania ekosystemów w różnych warunkach krajobrazowych na obszarze leśnych kompleksów promocyjnych: Ocena stopnia zrównoważenia gospodarki leśnej metodami energetyki ekologicznej [Energy balance of ecosystems development in different landscape conditions in promotional forest complexes: Evaluation of forestry sustainability by ecological energetics methods], manuscript., UMK, Toruń.

Nienartowicz A. \& Barcikowski A., 1996, Wykorzystanie energii słonecznej przez fitocenozy leśne jako wskaźnik ich zrównoważenia ekologicznego [Utilization of Solar energy by forest phytocenoses as indicators of their ecological equilibrium], Sylwan CXL(1): 71-80.

Nienartowicz A., Deptuła M. \& Domin D. J., 2008, Zmiany w przepływie energii przez wybrane jednostki go- 
spodarcze w kluczu zaborskim od XIV do XVIII w. [Cultural energy consumption and human influence on the structure of landscape in the Zabory Demesne in the 15 th -18 th c.], Kwartalnik Historii Kultury Materialnej 2008(3-4): 375-395.

Nienartowicz A., Domin D. J., 2007, Cultural energy consumption versus landscape structure, Ecological Questions 8: 3-23.

Nienartowicz A., Domin D. \& Kunz M., 2003, Influence of social infrastructure extension and changes in inhabitants' lifestyle on energy consumption in the village Asmus (Northwestern Poland), Ecological Questions 3: $139-152$.

Nienartowicz A., Filbrandt-Czaja A., Deptuła M. \& Boiński M., 1998, Changes in land use and their effect on species diversity and above-ground standing crop in the surroundings of lake Milachowo, [in:] S. Borsuk (ed.) Research of the lakes in national parks and other protected areas, II Int. Scientific Conference, Inst. Wyd. Habitat, Bydgoszcz: 20-31.

Nienartowicz A., Kunz M., Deptuła M. \& Domin D., 2002, Ecological consequences of changes in landscape structure in the neighbourhood of Brusy in 19th and 20th century, Ecological Questions 1: 117-135.

Nishizono T., Iehara T., Kuboyama H. \& Fukuda M., 2005, A forest biomass yield table based on an empirical model, J. For. Res. 10: 211-220.

Oleksowicz A. S., 1980, Zbiorowiska glonów planktonowych i epifitonowych w trzech limnologicznie zróżnicowanych jeziorach obszaru Borów Tucholskich, Rozprawa doktorska [Planctonic and epiphytic algal communities in three limnologically different lakes of Tuchola Forest area, Doctoral Thesis], UMK, Torun.

Oleksowicz A. S., 1986, Planctonic and epiphytic algal communities in three limnologically different lakes of Tuchola Forest area, II. Characteristics of components, seasonal quantitative changes and species diversity, Acta Univ. Nicolai Copernici, Limnological Papers 15: 49-73.

Orzeł S., Socha J., Forgiel M. \& Ochał W., 2000, Struktura biomasy podszytu występującego w drzewostanach Puszczy Niepołomickiej [Undergrowth biomass structure in the stands of Niepołomicka Forest], Sylwan CXLIX(4): 40-47.

PNBT, 2009, http:// www.park.borytucholskie.info, Official homepage of Tuchola Forest National Park, Information about National Park, map and log, Consulted at 21-08-2009.

Rejewski M., 1981, Roślinność jezior rejonu Laski w Borach Tucholskich [Lake vegetation of the Laska region in the Tuchola Forest], Wyd. UMK, Torun.

Ryszkowski L., 1984, Ekologiczne zasady kształtowania obszarów wiejskich [Ecological rules for development of rural areas], Zagadnienia Ekonomiki Rolnej 1/84: $16-22$.

Schandl H. \& Schultz N., 2002, Changes in the United Kingdom's natural relations in terms of society's metabolism and land-use from 1850 to the present day, Ecological Economics, Special Section: European Environmental History and Ecological Economics 41: 203-221.

Smith J. E., Heath L. S. \& Jenkins J. C., 2003, Forest volume-to-biomass models and estimates of mass for live and standing dead trees of U.S. forest, General Technical Report, United States Department of Agriculture, Forest Service, Retrieved from: http://www.uvm.edu/ jcjenkin/ smith\%20et\%20al.\%202003.pdf at 1 July 2009.

Szymański S., 1970, Ukształtowanie niepielęgnowanych drzewostanów sosnowych I i II klasy wieku pod wpływem procesu naturalnego wydzielania się drzew [Development of untended pine tree stands of I and II age class under the influence of the process of natural isolation of trees], Prace Komisji Nauk Rolniczych i Komisji Nauk Leśnych PTPN 30: 289-306.

Szymkiewicz B., 2001, Tablice zasobów i przyrostu drzewostanów ważniejszych gatunków drzew leśnych [Tables of resources and stand increment of major forest tree species], PWRiL, Warszawa.

Titlyanova A. A. \& Kosykh N. P., 2000, Changes in plant cover and net primary production in the forest-steppe zone of West Siberia, [in:] P. S. White, L. Mucina, J. Lepš (eds.), Vegetation science in retrospect and perspective, Proceedings of the $41^{\text {st }}$ IAVS Symposium, 26 July-1 August 1998, Uppsala: 279-282.

Vitousek P. M., Ehrlich P. R., Erlich A. H. \& Matson P. A., 1986, Human Appropriation of the Products of Photosynthesis, BioScience 36(6): 368-373.

Vitousek P. M., Mooney H. A., Lubchenco J. \& Melillo J. M., 1997, Human Domination of Earth's Ecosystems, Science 277(5325): 494-499.

Weisz H., Fischer-Kowalski M., Grünbühel C. M., Haberl H., Krausmann F. \& Winiwarter V., 2001, Global Environmental Change and Historical Transitions, Innovation 14(2): 117-142.

Whittaker R. H., 1975, Communities and ecosystems, 2nd edition, Macmillan, New York.

Wilkoń-Michalska J., Lipnicki L., Nienartowicz A. \& Deptuła M., 1998, Rola porostów w funkcjonowaniu borów sosnowych [The role of lichens in functioning of pine forests], [in:] K. Czyżewska (ed.), Różnorodność biologiczna porostów [Lichen biological diversity], Wyd. UŁ, Łódź: 103-121.

Wilkoń-Michalska J., Nienartowicz A., Kunz M. \& Deptuła M., 1999, Old land-use maps as a basis for interpreting of the contemporary structure of forest communities in Zabory Landscape Park, Phytocoenosis 11: 139-154. 
Williams M., 2000, Dark Ages and Dark Areas: Global Deforestation in the Deep Past, Journal of Historical Geography 26(1): 28-46.

Wright D. H., 1990, Human impacts on the energy flow through natural ecosystems, and implications for species endangerment, Ambio 19(4): 189-194.

Zaborski B., 1932, O mapie Prus Królewskich i Książęcych Schröttera [About the Schrötter's map of Royal and Ducal Prussia], Sprawozdania z Czynności i Posiedzeń Polskiej Akademii Umiejętności XXXVII(10): 32.
Zaborski B., 1935, Kaszuby na przełomie XVIII i XIX wieku w świetle mapy Schröttera-Engelhardta $\mathrm{z}$ lat 1796-1802 [Die Kaschubei am Anfang des XIX. Jahrhunderts im Lichte der Karte von Schrötter-Engelhardt A.D. 1796-1802], Wiadomości Służby Geograficznej 18: 239-262.

ZPK, 2009, http://www.zaborypark.eco.pl Zaborski Park Krajobrazowy, Official homepage of Zaborski Landscape Park. Information about Landscape Park, map and $\log$. 